\title{
Effect of different newer pesticides on aphid population of summer okra
}

\author{
Y.T. JADHAV*, S.R. MANE ${ }^{1}$ AND D.S. SHINDE ${ }^{2}$ \\ Department of Agricultural Entomology, Ratnai Agriculture College, AKLUJ (M.S.) INDIA \\ ${ }^{1}$ Department of Horticulture, Ratnai Agriculture College, AKLUJ (M.S.) INDIA \\ ${ }^{2}$ Department of Agricultural Entomology, College of Agriculture, PANIV (M.S.) INDIA
}

\section{ARITCLE INFO}

Received : 14.06 .2016

Revised : 09.08.2016

Accepted : 23.08.2016

\section{KEY WORDS :}

Bio-efficacy, Imidacloprid, Thiamethoxam, Fipronil, Diafenthiuron

*Corresponding author:

Email : rupayogeshjadhav@gmail.com

\section{ABSTRACT}

The studies on bio-efficacy of aphid population showed quite promising results and from the pooled data at first spray, the results revealed that all the treatments proved their superiority over untreated control showing imidacloprid $70 \mathrm{WG}$ as the most effective treatment followed by thiamethoxam $25 \mathrm{WG}$, fipronil $5 \mathrm{SC}$ and diafenthiuron 50WP. The second spray results showed that thiamethoxam $25 \mathrm{WG}$, imidacloprid $70 \mathrm{WG}$ and fipronil 5SC proved to be the best treatments with maximum reduction of population and were found at par with each other.

How to view point the article : Jadhav, Y.T., Mane, S.R. and Shinde, D.S. (2016). Effect of different newer pesticides on aphid population of summer okra. Internat. J. Plant Protec., 9(2) : 418-423, DOI : 10.15740/HAS/IJPP/9.2/418-423. 